\title{
Corrigendum: ASC filament formation serves as a signal amplification mechanism for inflammasomes
}

\author{
Mathias S. Dick, Lorenzo Sborgi, Sebastian Rühl, Sebastian Hiller \& Petr Broz
}

Nature Communications 7:11929 doi: 10.1038/ncomms11929 (2016); Published 22 Jun 2016; Updated 17 Mar 2017

In this Article, residues D128 and D132 of ASC are consistently referred to incorrectly as D130 and D134, respectively. These errors appear in the Results, Methods, Fig. 2, Fig. 3 and Supplementary Fig. 1.

\footnotetext{
(c) This work is licensed under a Creative Commons Attribution 4.0 International License. The images or other third party material in this article are included in the article's Creative Commons license, unless indicated otherwise in the credit line; if the material is not included under the Creative Commons license, users will need to obtain permission from the license holder to reproduce the material. To view a copy of this license, visit http://creativecommons.org/licenses/by/4.0/

(C) The Author(s) 2017
} 